\section{Women Empowerment in Rural Bangladesh: The Role of Local Institutions}

Rakibul Ahasan ${ }^{1}$, Md. Nazmul Hoda, Mehedi Mudasser

\section{Abstract}

Similar to the rest of the world, women empowerment in rural Bangladesh is growing as one of the most critical issues need answering very soon. Several attempts have been undertaken by different government organizations, local government institutions, and non-government organizations in recent years to empower the women in various facets- social, economic and political for the least. The objective of this paper was to evaluate the women empowerment status in a rural area in Khulna district, Bangladesh. Physical surveys were conducted among the households in the Chakrakhali village under Jalma Union in Batiaghata Upazilla of Khulna district. The samples were randomly drawn from the families in the area irrespective of economic, social or religious characteristics. All the respondents were adult women-either the household head of women lead household or the housewife of the family. The social, economic, and political empowerment status of the women in the village was evaluated through the study. The findings from the survey indicate the women are empowered mostly in the economic realm, followed by social empowerment. The political empowerment of the women of that village found to be absent in most cases. The survey results also indicated that the household heads hinder the political and social empowerment status of the women in a male-lead household. In these types of families, despite the monetary or other supports form the institutions is delivered to the women, they are not the own making the decisions. It is found that a lot of the choices of the women are influenced by the household head, mainly to borrow money from micro-credit organizations. The understanding between government organizations and women are not in good shape as women are not interested in the functions of these organizations in most of the cases. Mainly the non-government organizations (i.e., CSS, BUREAU Bangladesh, ASA, PROSHIKA, BRAC, Grameen Bank, etc.) work for the villagers, and women are more concerned about the activities of these institutions. However, it was found from the study that women are not being benefitted and mainstreamed through empowerment activities by these institutions.

Keywords: Women empowerment; social empowerment; economic empowerment; political empowerment; non-government institutions; institutional mapping.

\section{Introduction:}

Empowerment may be defined as a method of increasing the economic, political, social, educational, gender, or spiritual strength of an individual or individuals. It can be defined as individual process of taking control of and responsibility for one's life and situation and defining it as a political process of granting human rights and social justice to disadvantaged groups of people.

Women empowerment can be defined according United Nations Development Fund for Women (UNIFEM), which includes the meaning- Acquiring knowledge and understanding gender relations, Developing a sense of self-worth, a belief in one's ability, Gaining the ability to generate choices and Developing the ability to influence and change the direction development and social change (Boraian, 2008). According to Bhasin (1985), involved the transformations of power relations in six different level- individual, family, group, organizations, village community and society. In order to empower the rural women, female development workers must empower themselves first (Boraian, 2008).

In general, women empowerment indicates the equality of women in the social decisionmaking process, their involvement in the social important matters and issues also the equality and access in terms of economic and political process and agenda. Developed countries are having an advantage that the women in these countries are comparatively more empowered in terms of social, economic and politics in compare to the women of less developed countries like South Asian countries e.g. Bangladesh, India etc. The subject of 
empowerment of women has becoming a burning issue all over the world including Bangladesh since last few decades. In Bangladesh, the condition of the women is kind of vulnerable especially in the rural Bangladesh. Despite a lot of Non-government, government initiatives are there, still women are not gaining the equal rights in the decisionmaking process and also their condition cannot be declared one of being empowered.

This study was conducted keeping in mind the aim of identifying the empowerment condition of the women of rural areas of Bangladesh. Identification the role of various organizations regardless of its ownership or licensing type (whether it is government or not) in empowerment process of the women is also the focus of this study. It was done in Batiaghata Upazilla under Khulna district.

This study was mainly focused on identifying the empowerment in terms of social empowerment, economic empowerment and political empowerment. Some definite parameters and indicators were used to serve the purpose. Indicators used in this study are-
a) Education
b) Health Care
c) Involvement in Decision making
d) Access to information
e) Economic Freedom (access to employment)
f) Public Participation
g) Freedom of mobility
h) Freedom to speak
i) Access to various govt. and non-govt. organizations
j) Government support.

The study was done through household interview survey and focus group discussion (FGD1) in the village Chakrakhali. It was done focusing social, economic and political empowerment status of the rural women. And the result founded indicates that level of empowerment is dependent on various correlated factors. It varies according to the change in the income level, condition of the housing, and also change of the housing structure type.

The aim of this study can easily be stated as to identify the level of empowerment of women's in the rural areas in Bangladesh and also to identify the role of various institutions i.e. the NGOs, various government organizations, CBOs and other co-operative organizations. Objective of this research study can also be identified straightforwardly from the aim as well. If the general objective of this study is tried to identify, it will simply the identification of women empowerment from three different perspective. The role of institutions and other indicators comes later in empowering these women of the rural areas of Bangladesh. General objective gives rise to some specific objectives alongside it. For this study the specific objectives were- To measure/assess women's economic, social and political empowerment in rural Bangladesh; and to explore the role of institutions in supporting or hindering economic, social and political empowerment of rural women.

\section{Methodology:}

Methodology describe the process of study that is followed by a researcher to achieve the targeted result and to conduct the study in a planned way. Methodology includes data collection and analysis and interpretation of results to generate findings. The success of any report depends mostly on its methodology. So, methodology is very important.

\section{Site selection}

Selection of the study area is a major part of the study. Proper selection of the study area represents the actual picture of the similar areas. So, selection of the study area is very essential. We have selected Chakrakhali village under Jalma Union at Batighata Upazilla of Khulna Zila to analyze the women empowerment in rural areas and the role of institutions both Local Government and the Non-Government Organizations.

\section{Questionnaire preparation and Survey operation}


Based on the assigning objectives the questionnaire is prepared. Mainly close ended questions (yes/no) are developed for more quantitative analysis. Besides this side getting qualitative data by the use of open-ended questions for exploring the role of institutions.

After setting all procedure we surveyed the study area especially through individual respondent key interviews and Focus Group Discussion. The respondents are the adult women (18-49), especially the wives of the household head. Selection criteria is the married adolescent because they are only the family members who can provide the actual information against the questions. The survey is conducted by the 8 members who surveyed 5 questionnaires individually. So total 40 questionnaires are surveyed which are attached to the report finally.

\section{Data Types}

Data type used was fully primary because there is no survey conducted in rural institutions both local governmental as well as NGOs. A large portion of the questionnaire is filled up by close ended questions. So, the quantitative data is prominent in that report than the qualitative data. But the role of institutions is fully covered by the open-ended questions and for which these are become more qualitative.

\section{Data Processing}

After finishing the survey operation and collecting information from the field survey, all the collected data were completed and presented in the tabular and graphical form. The interpretation of data relating to the objectives of study has been presented in the report.

\section{Data Analysis}

After processing the collected data from survey operation have been analyzed for understanding the women empowerment in rural Bangladesh and the role of institutions: a case study of Chakrakhali village. Collected data have been analyzed to imbibe findings/observations based on real experience in field survey. All data are presented in tabular form using the computer software named SPSS, MS Word and MS Excel and analyzed according to objectives of the study. Most attention is given in this phase because any wrong observation might cause wrong result. Finally, this analyzed data have been presented in the report.

\section{Study Area:}

Batiaghata Upazilla (Khulna district) with an area of $248.33 \mathrm{sq} . \mathrm{km}$, is bounded by Kotwali (Khulna), Dumuria and Rupsa Upazilla and Sonadanga Thana on the north, Dumuria Upazilla and Paikgachha Upazilla on the west, Dacope, Paikgachha and Rampal Upazilla on the south, Rampal, Fakirhat and Rupsha Upazilla on the east. The main rivers are Kazibachha, Shoilmari, Salta, Jhopjhopia, Pasur, Sibsa, Rupsha and Nalua. The Upazilla consists of 7 unions: Amirpur, Gangarampur, Jalma, Batiaghata, Baliadanga, Bhanderkote and Surkhali. Chakrakhali is the village where the study has been conducted is under the Jalma Union. Here the total number of households is 13243 and the population,

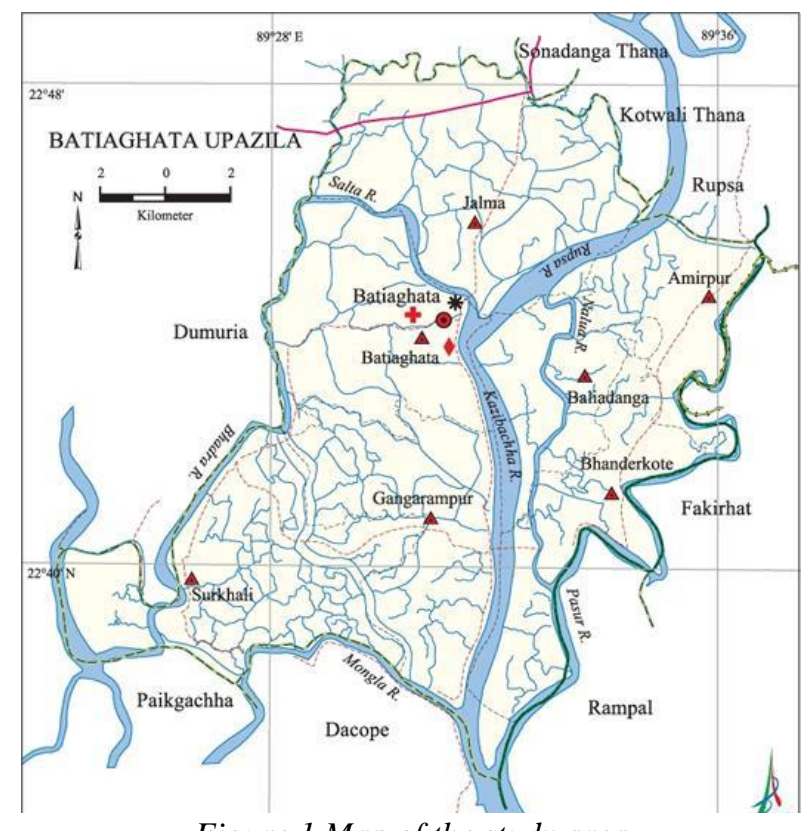

Figure 1 Map of the study area

59025. Whatever, for the Chakrakhali village the latitude and longitude are $22^{\circ} 45^{\prime} 20.8^{\prime \prime}$ $\left(22.7558^{\circ}\right)$ north and $89^{\circ} 31^{\prime} 26.2^{\prime \prime}\left(89.5239^{\circ}\right)$ east respectively. Its average elevation is 5 meters (16 feet). Total population of the village 
is 1169. Among the Muslim people are only 111 and the Hindus, 1056 and the Christians only 2. About 257 households exist, and the literacy rate is $53.35 \%$.

\section{Conceptual Framework:}

Empowerment is probably the totality of the following or similar capabilities: Having decision-making power of their own; Having access to information and resources for taking proper decision; Having a range of options from which individuals can make choices (not just yes/no, either/or.); Having positive thinking on the ability to make change; Ability to learn skills for improving one's personal or group power; Involvement in the growth process and changes.

On the other hand, institution are the kinds of structures that matter most in the social life: they make the stuff the social life. The increasing acknowledgement of the role of institutions in social life involves the recognition that must of human interaction and activity is structured in terms of obvious or implicit rules. Institutions are the organizations which works with or deals with, also enables order, thought, expectations and actions by imposing from and consistency on human activity.

It is an assumption which have a large market all around the world that institutions play a role in empowerment process and also women empowerment process as well. Considering the economic, social and political phenomena of empowerment, role of institutions is inevitable. Social indicators are used to measure the change in the social relationship of the people. Political indicators are used to measure the change in the power structure or measuring political change. Economic indicators are used to measure the changes of economic structure of target population. Also, in the study it has been found that institutions do play a role in women empowerment. Micro finance organizations do play a proactive role in the process. These organizations increase the involvement of women in the economic term. But it also does have some negative influence as most involvements are not selfmotivated. Again, role of political institutions is also not very much helpful in the process of women empowerment. But despite all these negative influences of the institutions active in the area, we considered that mostly these institutions influence the empowerment process positively.

\section{Data Analysis}

An intensive field survey was performed in order to collect relevant data on women empowerment which was done by talking to the women respondents based on a predesigned questionnaire. Afterwards, focus group was formed and mainly the role of institutions and involvement of the institutions in that particular area was the focus of that discussion session. Despite having a series of drawbacks and constraints e.g. lack of willingness of female participants and respondents in providing data about their conditions, also disparity of the households in the area hinders the process at large. Still data were collected by individual household survey on 40 households keeping focus on the structure type. The ratio that were followed for katcha: pucca: semi-pucca were 3:1:1. So the total pucca and semi pucca households that were surveyed were 8 each, and katcha households were 24.The collected data were inputted in a database using SPSS and statistical analysis was performed to gain some statistical know how about the empowerment of that areas women's based on the field survey. 


\section{Existing Conditions in The Study Area}

Before analyzing the empowerment data and parameters, it is important to be informed about the existing condition of the study area in some aspect

\section{Family Types}

We tried to figure out the family types in the study area whether it is single nuclear family or a joint family with multiple households. Most of the families in survey found out to be single nuclear family. Almost $78 \%$ of the families are single family in the survey. It indicates the truth that has been said in various literature over the years that the trend and culture of joint family in Bangladesh are breaking gradually. And the dominance of single families is increasing whereas not very long ago the scenario was different.

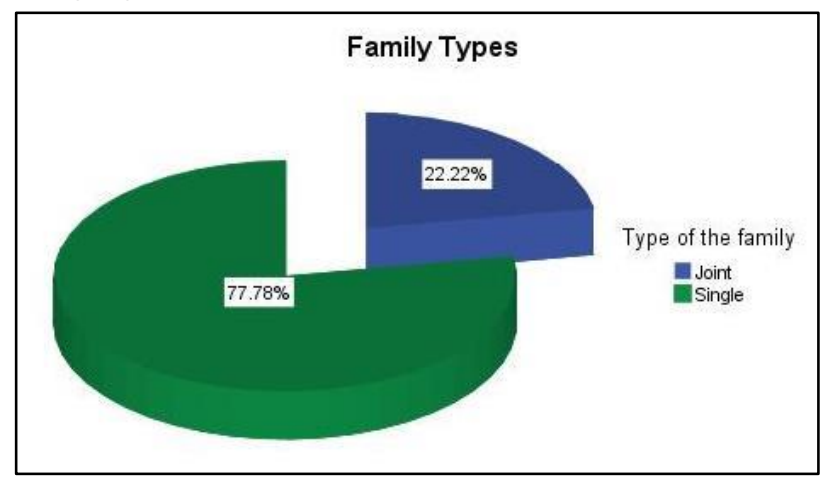

Figure 2 Family types

\section{Religion}

Bangladesh being Muslim dominated country, the study area seemed to be dominated by the other religion people specially the Hindu's. Almost one third of the respondents were

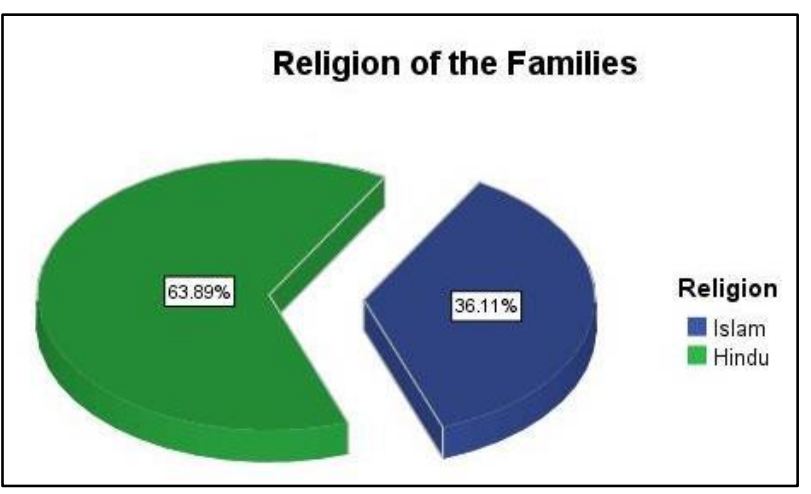

Figure 3 Religion of the Families found to be follower of Hindu religion. And other religions like Christian, Buddhist and other spiritual followers were not found in the field survey.

\section{Occupation Pattern}

Severe diversity was noticed when it was tried to identify the occupation of the household head in the survey process. Surprising was that even student came out as the household head as the male member is either absent due to death or other unavoidable circumstances. Most dominant occupation group was identified as the farmers who occupied almost one fourth $(25 \%)$ of the occupation pattern. Drivers of various transport modes running in the area and nearby areas are the next dominant occupation group (19\%), followed by the day laborer groups (14\%). Among other groups some informal business groups can be mentioned.

Import thing to notice is that almost all the occupations are of low-income generating options. None of these occupations are neither formal nor high yield providing. That indicates to the vulnerable condition in terms of economic conditions in the study area.

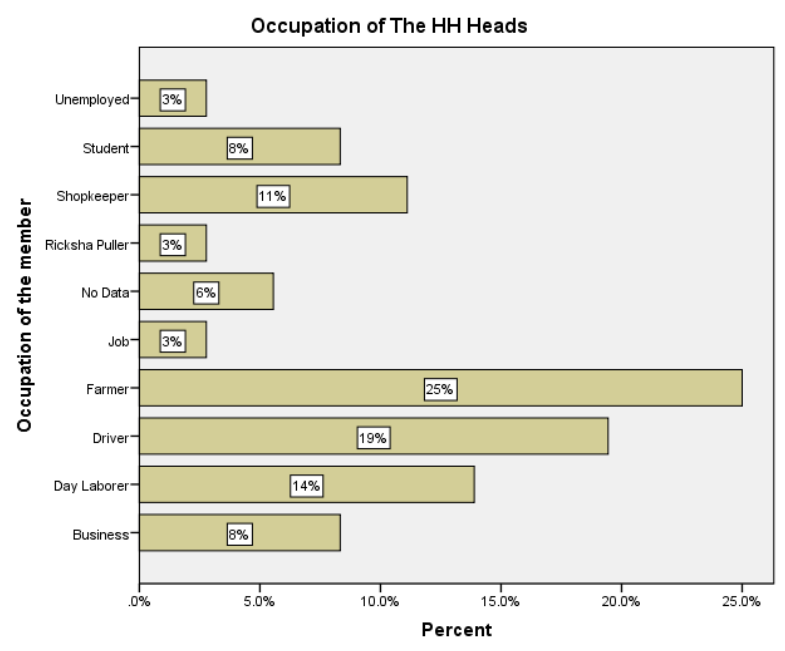

Figure 4 Occupation of the HH Head

\section{Measuring Women Empowerment}

It was stated earlier that the empowerment measurement was done keeping focus on three types of empowerment- social, economic and political. And to serve this purpose some indicators were used which were stated earlier 
in the background section. Now let's move on to empowerment measurement based on the data collected from the field.

\section{Social Empowerment}

Social empowerment indicates to the state when women are allowed to have freedom of movement and have some role in decision making in and outside of the society. Indicators used to measure social empowerment were
a. Involvement in Decision making
b. Public Participation
c. Freedom of mobility
d. Health care

Data collected for social empowerment measurement can be portray as below-

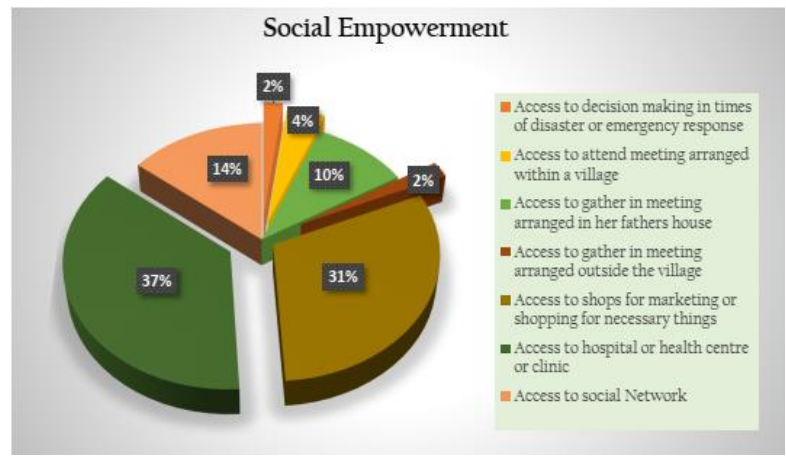

Figure 5 Level of social empowerment

Now if the relation is built between social empowerment indicators and other parameters like family type and housing type that will give other dimensions of social empowerment as well. Like it will describe the relationship among empowerment and poverty or empowerment through structure types as well.

\section{Residence Type \& Social Empowerment}

It is stated earlier the ratio on which structure types were selected when conducting the field survey. The ratio was 3:1:1 for katcha: semi pucca: pucca. It also found that there is an underneath relationship among these two different parameters as well. Most likely that people living in pucca houses do enjoy more freedom than of those in semi pucca and katcha houses.

Although some data indicates that semi pucca household are more empowered than those of pucca households. It's mostly because of the lack and faults in data.

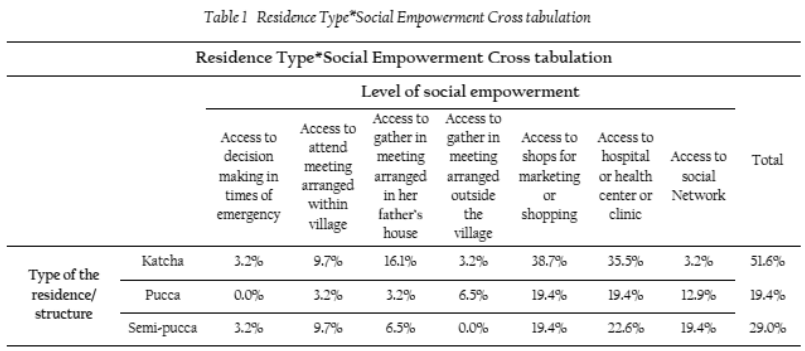

\section{Family Type \& Social Empowerment}

Relation between family types and social empowerment was also identified based on the defined indicators. Being dominated by single family households it is obvious women of these families are more empowered according to the indicators defined. And it is also well known that culturally and traditionally joint families are more conservative than those of single family.

Involvement in Decision making, Public Participation and Freedom of mobility were the three indicators taken into consideration for social empowerment measurement. Analyzing the data collected from field, it can be concluded that level of social empowerment varies based structure types where the women are living, also changes according to change in their family types. Single family living in pucca or semi pucca structures-these women are more empowered than those living in katcha houses and in joint large families.

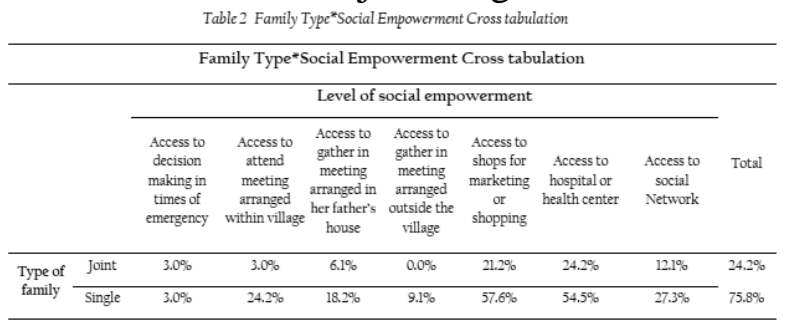

\section{Economic Empowerment}

Economic empowerment may be defined as the involvement of female members of a family in the income generating options and as well as to freedom to pursue it. In this study the indicators that were used to identify level of economic empowerment were 

a. Economic freedom (access to employment) and
b. Access to various govt. and non-govt. organizations.

For this purpose, it is important to identify the involvement of female members of a family in its total monthly income.

\section{Family Income Pattern}

Occupation of the household heads were discussed in the previous sections. That indicates the truth of people's involvement in the low-income generating works like farming. This reflects in the monthly income pattern of the families. If we look upon the chart of monthly income of the households surveyed it will give us the information that most influential income group is the 3-7 thousand (nearly $53 \%$ of total population) which justifies the previous analysis of low income as well (Figure 06).

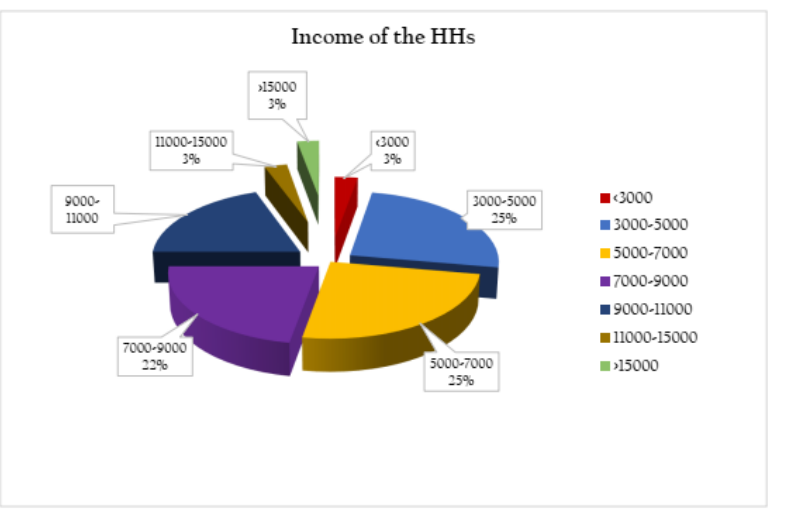

Figure 6 Income of the Households (Source: Field survey, 2014)

${ }_{2}^{2}$ Here employment includes all income generating options. It may be formal or may not be. And also it includes the
options to choose and choice of it as well.

Figure 6 Income of the Households

\section{Female Involvement in Family Income}

In order to measure economic empowerment of women, it is important to identify their involvement in the monthly family income. This will give us an idea on the level of their concurrent participation in the economic activities before going to further analysis.

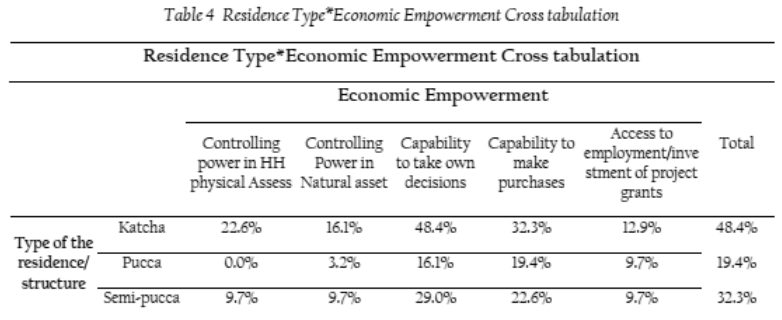

As the total family income is very low to maintain the living of the households, most of the women in rural areas do engage themselves in various income generating works like handicrafts. The study area is not an exception to this. That's what reflects in the findings of female involvement in the family income. More than two third of the respondents said that they have contribution to monthly family income (figure 07).

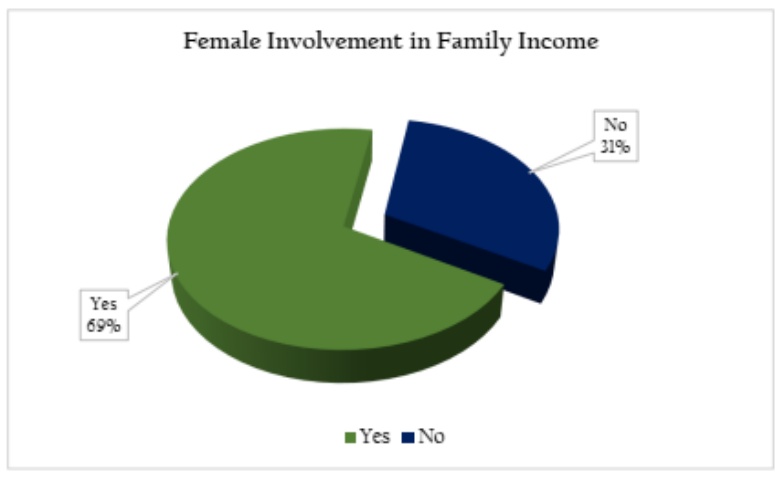

Figure 7 Female Involvement in Family Income

\section{Family Type*Economic Empowerment}

Like the analysis in social empowerment, attempt was made to identify the relationship between family type and economic empowerment parameters.

Family type do influence the economic empowerment level, just like it does in the case of social empowerment. Most of the women of single-family household has more access to economic activities, freedom to economic activity and control of family assets than the women in the joint families (table 3 )

\begin{tabular}{|c|c|c|c|c|c|c|c|}
\hline \multicolumn{8}{|c|}{ Family Type*Economic Empowerment Cross tabulation } \\
\hline & & \multicolumn{5}{|c|}{ Level of Economic Empowerment } & \multirow[b]{2}{*}{ Total } \\
\hline & & $\begin{array}{c}\text { Controlling } \\
\text { power in HH } \\
\text { physical } \\
\text { Assess }\end{array}$ & $\begin{array}{l}\text { Controlling } \\
\text { Power in } \\
\text { Natural asset }\end{array}$ & $\begin{array}{l}\text { Capability } \\
\text { to take } \\
\text { own } \\
\text { decisions }\end{array}$ & $\begin{array}{l}\text { Capability to } \\
\text { make } \\
\text { purchases }\end{array}$ & $\begin{array}{c}\text { Access to } \\
\text { employment/ } \\
\text { investment of } \\
\text { project grants }\end{array}$ & \\
\hline \multirow{2}{*}{$\begin{array}{l}\text { Type of } \\
\text { the family }\end{array}$} & Joint & $3.2 \%$ & $6.5 \%$ & $22.6 \%$ & $19.4 \%$ & $6.5 \%$ & $22.6 \%$ \\
\hline & Single & $29.0 \%$ & $22.6 \%$ & $71.0 \%$ & $54.8 \%$ & $25.8 \%$ & $77.4 \%$ \\
\hline
\end{tabular}




\section{Residence Type*Economic Empowerment}

Residence type has also some relation to do with economic empowerment. From the table below (table 4) (if converted to uniform ratio) pucca household women do have better access and control on economic resources than those of katcha households.

\section{Involvement with Government and Non- Government Organizations}

To assess economic empowerment, it is important to identify activity of various govt. and non govt. organizations especially those which deals with micro credit or provide finance to the peoples of rural areas. Involvement will indicate the level of freedom in economic activities which eventually indicates to empowerment of women economically.

\section{Involvement with $\mathrm{NGOs} / \mathrm{MCO} s$}

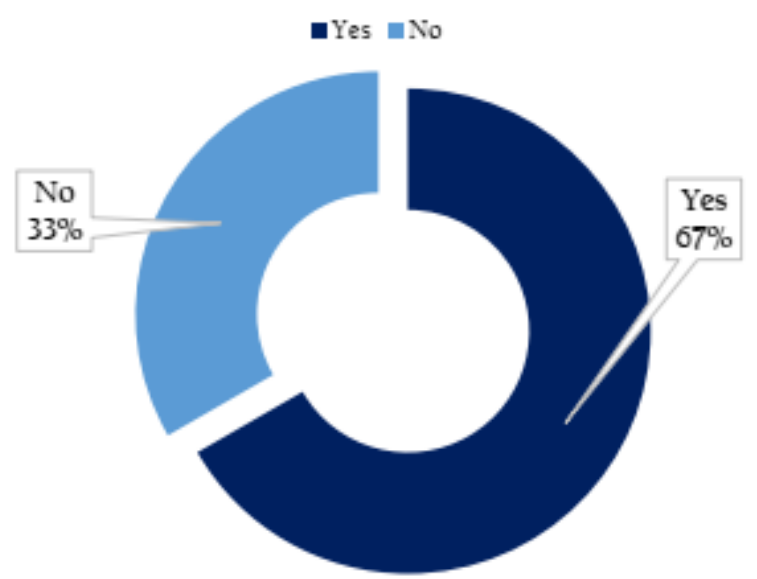

Figure 9 Involvement of women with NGOs/MCOs

\section{Motivation Behind Involvement}

Despite of this high rate of involvement, most of the women are not involved on their own. Most of them are forced to join in the program

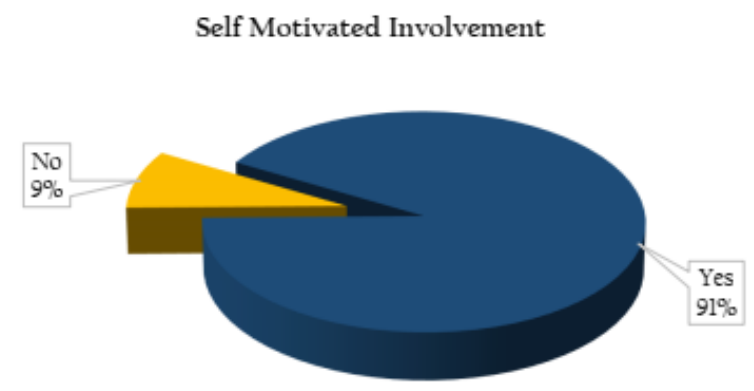

Figure 8 Self Motivated involvement or involved with the NGOs. This force can be their family, but it can be unavoidable situations like disasters as well.

\section{Benefit from Involvement}

Although the level of participation and involvement with the NGOs and MCOs are pretty high in number, not a good number of people are getting benefit from it. That's what came out from the field survey. Only about $12 \%$ women said they actually get any benefit from being involved with these NGOs and MCOs.

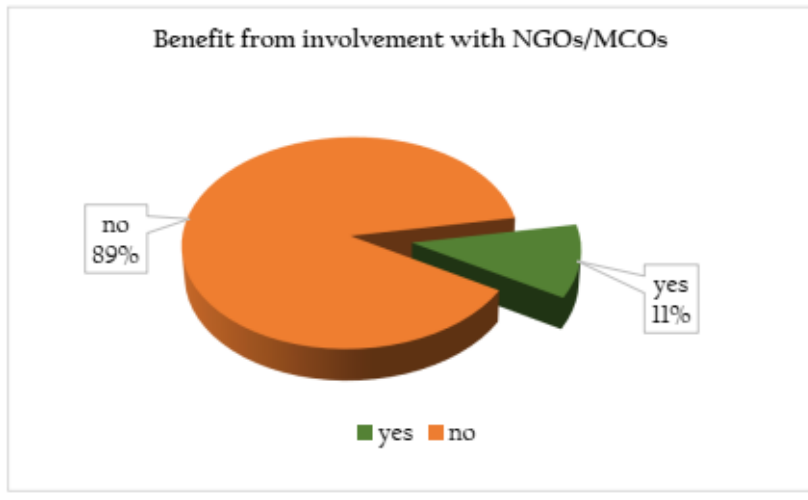

Figure 10 Benefit from involvement with NGOs/MCOs

\section{Role of Institutions}

It is difficult for both government and nongovernment organizations to play any role in social empowerment. But it is a lot easier to provide incentive in empowering women economically. That's why there is a number of micro finance organizations working in the area. For example, we can consider the names which came out from the survey-

- BRAC

- ASA

- PROSHIKA

- Grameen Bank (GB)

- CSS \&

- Bureau Bangladesh

These organizations help the women with financial support to begin their own entrepreneurship and become self-reliant and provide financial support to their families. But there found the absence of government organizations in this prospect in the study area. 


\section{Political Empowerment}

Political empowerment simply indicates the involvement of women in the political process or even the participation in any political activity at all. It is difficult to judge the level of empowerment in terms of political empowerment as in Bangladesh politics is sort of tabooed to discuss about. And for women it's kind of banned. Yet some data were collected regarding this perspective. And unlike social and economic empowerment measurement process, these data are also presented in comparison with housing type and family types.

\section{Housing Type*Political Empowerment}

Unlike other two empowerment, in this case katcha housing residents are more active in the political process, although still the pucca housing residents have more access to political activities like other two dimensions of empowerment.

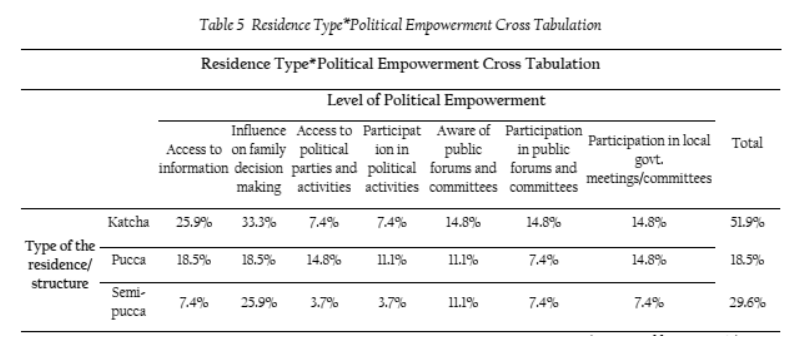

\section{Family Type*Political Empowerment}

Likewise, single family household women do have more participation and access to political parties or those activities which will eventually make them empowered. And the joint family women are as usual are deprived compared to those of single family.

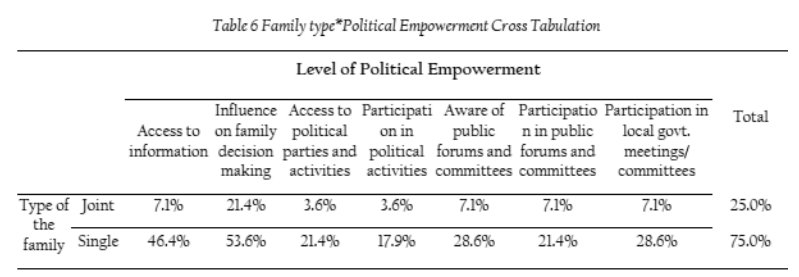

\section{Map of Institutions}

Based on the data collected from the field, an attempt was made to prepare an institutional map showing the influence and availability of the institutions in the study area. The Map can be drawn as it has been done in figure 11-

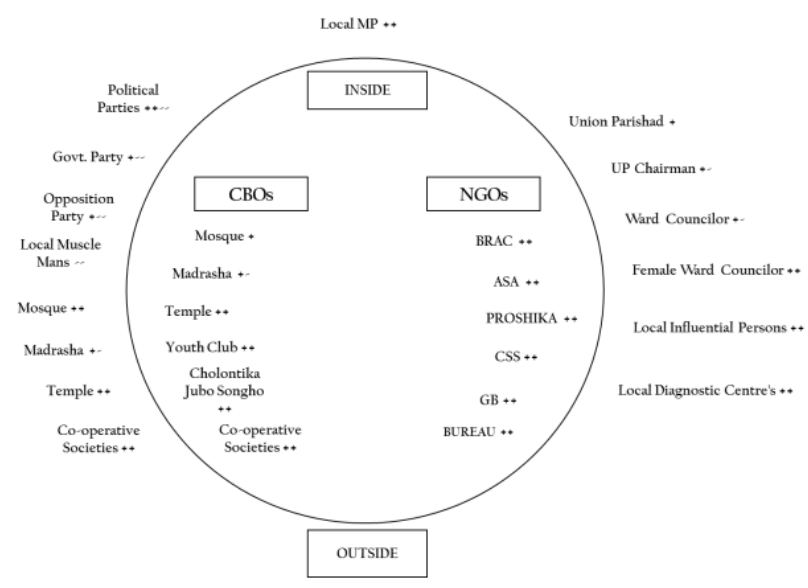

Figure 11 Institutional Mapping

Although this data is not appropriate to make such an institutional map still it may be useful to identify the available NGOs and CBOs and other factors influencing women empowerment in the area in the long run.

\section{Focus Group Discussion}

As stated earlier a focus group is a form of qualitative research in which a group of people are asked about their perceptions, opinions, beliefs, and attitudes towards a product, service, concept, advertisement, idea, or packaging. A focus group discussion is conducted in order to ensure the people's participation in the social process or even in the planning process. Focus group helps in verifying the data collected from the field survey. The aim to conduct FGD in this study was to identify the role of various institutions in empowering the rural women in the study area. It was done using a semi structured interview format prepared earlier.

Constraints in conducting FGD was the unwillingness of the women to participate in the process. And the spatial distribution of households in the study area was another major problem in performing FGD. We managed 3 
women despite all these constraints. The finding are mostly the names of organizations those are involved with the economic and other process of rural women empowerment process. Mostly NGOs in the area deals with Microfinance or micro credit. Women involvement are also with an intention to gain economic benefit. We found that some cooperatives are there as well at the same time alongside the NGOs and CBOs.

\section{OBSERVATIONS}

It is tough to identify the actual economic condition of the household. For example, one respondent's family have a car and three storied building, but income is only $6000 \mathrm{tk}$. This is very much unethical. Almost all are Hindus for which the people are motivated by the cultural activities of this religion. This is how the interaction among the people attained. To conduct Focus Group Discussion became tough as the houses are so more dispersed. So, the women of different households didn't agree to this discussion as one house is far from the other. So, the minimum number of respondents couldn't be possible to get together. Whatever, it was possible to coincide three respondents. Katcha and semi pucca house types are available and the number of pucca building is not like those.

\section{CONCLUSION}

The report of "Women's Empowerment in Rural Bangladesh: The Role of Institutions" is such a study which has conducted in the area of Chakrakhali village under Jalma union of Batiaghata Upazilla, Khulna district. The paper shows the economic, social and political empowerment of rural women and the role of institutions in supporting or hindering empowerment. A great number of the people are Hindus and few are Muslims. The condition of women of different households are more or less same. They have no involvement in political issue. So, they are politically disempowered in political sector. But economically they become empowered by mostly the non-government organization and few by the local government organization.
The awareness among the women because of economic suppression is understood clearly to see the activity. About 10 or 15 women create a group for some specific purposes like livestock, irrigation etc. But this empowerment is not seen in all households as hindered the power of the household head. In this type of family, the money or other provided by the institutions is handover from the women. Whatever, in some family's women have the contribution to the family income, savings and expenditure which raise the confidence in terms of economic perspective. But the social empowerment of the women is moderately in satisfactory level. Because now these women have the accessibility to go to the hospital, school, market etc. The NGOs involvement is a big issue functions behind the empowerment of rural women. Many activities are only conducted for the women. BRAC, ASA, CSS, Bureau of Bangladesh, Chalantika Juba Sangha, PROSHIKA, Grameen Bank etc. which are responsible for mainstreaming the rural women in different social and economic activities. There is no doubt that these NGOs play a great role in this purpose. But the relation to the local government institutions as well as the activities are not in the satisfactory level. So, the central government has to concentrate in this issue as the women is the half of a society as encourage the local institutions through financial support by decentralization. So, a good policy and the awareness in all strata of the people can empower the women through mainstreaming like our developing country, Bangladesh.

\section{References}

[1] Boraian, M. "Empowerment of Rural women: The Deterrents and Determinants", 1st ed. New Delhi: Concept Publishing Company, 2008.

[2] Islam F., "An Empirical Analysis on Women Empowerment of Some Selected Areas of Bangladesh". Bus Eco J 6: 166. 2015 doi:10.4172/2151-6219.1000166

[3] Paul G. K., Sarkar D. C., Naznin S. "Present Situation of Women Empowerment 
in Bangladesh" International Journal of Mathematics and Statistics Invention (IJMSI)

E-ISSN: 2321 - 4767, P-ISSN: 2321 - 4759

Volume 4, Issue 8, October. 2016, PP-31-38

[4] Mahmud S., Shah N. M., Becker S., "Measurement of Women's Empowerment in Rural Bangladesh". World Development Vol. 40, No. 3, pp. 610-619, 2012 doi: 10.1016/j.worlddev.2011.08.003

[5] Orso C. E. \& Fabrizi E., "The Determinants of Women's Empowerment in Bangladesh: The Role of Partner's Attitudes and Participation in Microcredit Programs". The Journal of Development Studies, 2016

DOI: 10.1080/00220388.2015.1107046

[6] Parveen S., Leonhäuser I., "Empowerment of Rural Women in Bangladesh: A Household Level Analysis". Conference on Rural Poverty Reduction through Research for

Development and Transformation, Deutscher Tropentag- Berlin, October 2004 